\title{
Jurist-Diction
}

Volume 4 No. 6, November 2021

\section{Aspek Hukum Pidana Penyiaran Film Tanpa Sensor oleh Netflix Sebagai Penyedia Layanan Subscription Video On Demand}

\author{
Aushofi Zuhrotul Ulya \\ aushofizuhrotululya@gmail.com \\ Universitas Airlangga
}

How to cite:

Aushofi Zuhrotul Ulya, 'Aspek Hukum Pidana Penyiaran Film Tanpa Sensor Oleh Netflix Sebagai Penyedia Layanan Subscription Video On Demand' (2021) Vol. 4 No. 6 Jurist-Diction.

Histori artikel: Submit 6 April 2021;

Diterima 15 Oktober 2021; Diterbitkan 5 November 2021.

\section{DOI:}

10.20473/jd.v4i6.31843

p-ISSN: 2721-8392

e-ISSN: $2655-8297$

\section{Abstract}

The new broadcast media is broadcast digitization in the form of a platform accessed via the internet network. Netflix as a provider of the Subscription Video on Demand service broadcasts uncensored films which result in the films being against the culture and laws and regulations in Indonesia because they contain pornography to violence even though there is an obligation to be censored by a film before the film will be shown. This research is a legal research that analyzes the uncensored film broadcasting activities carried out by Netflix according to the laws and regulations in Indonesia and Netflix's legal liability for uncensored film broadcasting by using a statutory approach and a conceptual approach. From this research it was found that Netflix broadcasts uncensored films in Indonesia in violation of the statutory provisions concerning Broadcasting, Film, Pornography, and ITE. However, Netflix does not automatically account for all provisions of the laws and regulations because the locus of broadcasting activities carried out by Netflix cannot be reached by all the provisions of the laws and regulations.

Keywords: Film Broadcasting; Netflix; Film Censorship; Internet.

\section{Abstrak}

Media penyiaran baru merupakan digitalisasi penyiaran dalam bentuk platform yang diakses melalui jaringan internet. Netflix sebagai penyedia layanan Subscription Video on Demand menyiarkan film tanpa sensor yang mengakibatkan filmnya bertentangan dengan budaya dan peraturan perundang-undangan di Indonesia karena bermuatan pornografi hingga kekerasan padahal terdapat kewajiban untuk dilakukan sensor film dikeluarkan oleh lembaga sensor film sebelum film akan dipertunjukkan. Penelitian ini merupakan penelitian hukum yang menganalisis kegiatan penyiaran film tanpa sensor yang dilakukan oleh Netflix menurut peraturan perundang-undangan di Indonesia dan pertanggungjawaban hukum Netflix terhadap penyiaran film tanpa sensor dengan mengggunakan pendekatan undang-undang dan pendekatan konseptual. Dari penelitian ini ditemukan bahwa Netflix melakukan penyiaran film tanpa sensor di Indonesia melanggar ketentuan peraturan perundang-undangan tentang Penyiaran, Perfilman, Pornografi, dan ITE. Namun, tidak serta merta semua ketentuan peraturan perundangundangan yang dilanggar dapat dipertanggungjawabkan pada Netflix karena locus kegiatan penyiaran yang dilakukan oleh Netflix tidak dapat dijangkau semua ketentuan peraturan perundang-undangan.

Kata Kunci: Penyiaran Film; Netflix; Sensor Film; Internet.

Copyright (C) 2021 Aushofi Zuhrotul Ulya 


\section{Pendahuluan}

Media penyiaran selalu berkembang mengikuti perkembangan teknologi informasi dan komunikasi yang dibuktikan dari penyiaran melalui media konvensional menggunakan spektrum frekuensi radio melalui udara serta kabel kemudian saat ini muncul media penyiaran baru yaitu media digital. Digitalisasi penyiaran dibuat dalam bentuk platform yang dapat diakses menggunakan jaringan internet. Platform-platform tersebut menyediakan berbagai jenis konten siaran, salah satunya film. Platform asing yang menyediakan siaran film di Indonesia, yaitu Netflix, Hooq, Viu, Iflix, dan Disney Plus.

Netflix dipilih untuk dijadikan sebagai objek penelitian hukum ini karena Netflix merupakan platform Video On Demand (VoD) asing pertama yang hadir di Indonesia pada Januari 2016, memiliki pelanggan terbanyak berdasarkan jumlah unduhan di Play Store sebanyak lebih dari 1 (satu) miliar kali, menawarkan banyak film serta Netflix memproduksi banyak konten original. ${ }^{1}$ Selain itu, Netflix memiliki fitur lebih baik dari pesaingnya yaitu parental controls yang berfungsi untuk menentukan film apa saja yang dapat ditonton oleh anak-anak. Layanan yang disediakan oleh platform asal California ini termasuk layanan Subscription Video on Demand (selanjutnya disebut SVoD) ialah, "refers to a service that gives users unlimited access to a wide range of programs for a monthly flat rate. The users have full control over the subscription, and can decide when to start the program". ${ }^{2} \mathrm{Hal}$ itu berarti bahwa konsep kegiatan SVoD yaitu memberikan akses pada pelanggan yang telah membayar tarif layanan untuk menonton siaran yang disediakan platform secara tidak terbatas.

Konten yang disiarkan Netflix memuat hal yang bertentangan dengan peraturan perundang-undangan di Indonesia yang mengakibatkan Telkom sempat memblokir Netflix sejak tahun 2016 sampai pada Juli 2020. Selain itu, alasan

\footnotetext{
${ }^{1}$ Conney Stephanie, 'Netflix Diunduh Lebih dari 1 Miliar Kali di Google Play Store', (Kompas.com, 2020) < https://tekno.kompas.com/ > accessed 22 November 2020.

${ }^{2}$ Techopedia, 'Subscription Video on Demand (SVoD)', (Techopedia, 2016) < https://www. techopedia.com/ > accessed 18 Agustus 2020 .
} 
Telkom memblokirnya karena Netflix tidak memiliki izin menyiarkan, tidak memiliki kantor di Indonesia, dan tidak membayar pajak. ${ }^{3}$ Netflix juga hadir di beberapa negara yang memiliki persoalan yang sama di Indonesia. ${ }^{4}$

Perkembangan penyiaran juga dapat dilihat dari perbedaan media yang disebutkan dalam definisi penyiaran pada Pasal 1 angka 1 Undang-Undang Nomor 24 Tahun 1997 tentang Penyiaran (selanjutnya disebut UU Penyiaran 1997) dan Pasal 1 angka 2 Undang-Undang Nomor 32 Tahun 2002 tentang Penyiaran (selanjutnya disebut UU Penyiaran). Selain itu, adanya kata 'media lainnya' dalam kedua Undang-Undang Penyiaran tersebut tidak dijelaskan media yang seperti apa namun hal itu menenunjukkan bahwa Undang-Undang Penyiaran dapat diterapkan pada media penyiaran baru selain yang disebutkan dalam definisi penyiaran pada kedua Undang-Undang. Ketua Komisi Penyiaran Indonesia (selanjutnya disebut KPI), Agung Suprio, menyampaikan bahwa beberapa narasumber menafsirkan bahwa kata 'media lainnya' UU Penyiaran dapat mencakup media baru seperti dengan melihat pada Undang-Undang Nomor 40 Tahun 1999 tentang Pers (selanjutnya disebut UU Pers) ditafsirkan sebagai media online. ${ }^{5}$

Berdasarkan Pasal 1 angka 5 jo. angka 6 Undang-Undang Nomor 11 Tahun 2008 jo. Undang-Undang Nomor 19 Tahun 2016 Tentang Informasi Dan Transaksi Elektronik (selanjutnya disebut UU ITE), platform yang melakukan kegiatan penyiaran dengan jaringan internet tersebut disebut sebagai penyelenggara sistem elektronik yang melakukan kegiatan penyiaran. Surat Edaran Menteri Kominfo Nomor 3 Tahun 2016 tentang Penyedia Layanan Aplikasi dan/atau Melalui Konten Internet (selanjutnya disebut SE Menteri Kominfo 3/2016) dikeluarkan sebagai akibat adanya persoalan mengenai penerapan regulasi antara UU ITE dengan UU

\footnotetext{
${ }^{3}$ Khamila Mulia, 'Netflix's complicated relationship with Indonesia', (Techinasia, 2020) $<$ https://www.techinasia.com/ > accessed 20 November 2020.

${ }^{4}$ Ikigai Law, 'Online content regulation: how is it done in other parts of the world?', (Ikigai Law, 2019) <https://www.ikigailaw.com/ > accessed 19 Desember 2020.

${ }^{5}$ Sherly Puspita, 'Kominfo: UU Penyiaran Saat Ini Belum Akomodasi KPI Awasi Media Baru', (Kompas.com, 2019) <https://entertainment.kompas.com/> accessed 18 Agustus 2020.
} 
Penyiaran, namun Surat Edaran ini tidak dapat dipaksakan keberlakuannya dan tidak mengandung sanksi sehingga hingga saat ini Netflix tidak mendirikan bentuk usaha tetap (selanjutnya disebut BUT) sebagaimana yang diwajibkan dalam SE Menteri Kominfo 3/2016.

Setiap film yang akan diedarkan dan/atau dipertunjukkan wajib disensor oleh Lembaga Sensor Film (selanjutnya disebut LSF) untuk memperoleh surat tanda lulus sensor (selanjutnya disebut STLS) sebagaimana disebutkan pada Pasal 57 ayat (1) Undang-Undang Nomor 33 Tahun 2009 tentang Perfilman (selanjutnya disebut UU Perfilman) dan pada Penjelasan Umum UU Perfilman paragraf kelima kalimat keempat. Kehadiran Netflix di Indonesia yang menyiarkan film tanpa sensor berakibat siaran tersebut bertentangan dengan nilai budaya Indonesia dan peraturan perundang-undangan di Indonesia. Berdasarkan hal tersebut diatas, maka perlu dikaji mengenai kegiatan penyiaran film tanpa sensor yang dilakukan oleh Netflix menurut peraturan perundang-undangan di Indonesia dan pertanggungjawaban hukum Netflix tekait penyiaran film tanpa sensor.

\section{Pendekatan Masalah}

Pendekatan yang digunakan dalam penelitian hukum ini adalah pendekatan undang-undang (statute approach) yaitu menelaah semua undang-undang dan regulasi yang bersangkut paut dengan isu hukum yang ditangani serta pendekatan konseptual yaitu memahami pandangan-pandangan dan doktrin-doktrin yang berkembang di dalam ilmu hukum. ${ }^{6}$

\section{Kegiatan Penyiaran Film Tanpa Sensor Yang Dilakukan Oleh Netflix Menurut Peraturan Perundang-Undangan Di Indonesia}

Indonesia pertama kali mengenal bioskop pada tanggal 5 Desember 1900 di Jakarta (Batavia), yang diadakan di rumah Schwarz, Kebondjae, Tanah Abang. Bioskop tersebut merupakan cikal bakal The Rojal Bioscope sebuah gedung

\footnotetext{
${ }^{6}$ Peter Mahmud Marzuki, Penelitian Hukum (Prenadamedia Group 2019).[47].
} 
bioskop pertama di Indonesia. ${ }^{7}$ Saat itu film lebih dikenal Gambar Idoep yaitu film documenter tanpa suara. ${ }^{8}$ Kemudian Film impor masuk ke Indonesia pertama pada tahun 1905 yang didatangkan oleh Amerika yang kemudian diterjemahkan ke dalam Bahasa Melayu. ${ }^{9}$ Film impor ini membawa daya tarik dan cukup diminati masyarakat yang mengakibatkan jumlah penonton meningkat dan banyak bioskop bermunculan di Indonesia.

Pada tahun 1926, film bisu lokal pertama diproduksi. Pada tahun 1931, Film bersuara hitam putih lokal diproduksi. ${ }^{10}$ Selain itu, film berwarna akhirnya mulai diproduksi dengan teknologi cinemascope pada tahun 1968. ${ }^{11}$ Teknologi produksi perfilman terus berkembang, dari accented cinema hingga multiplex cinema. ${ }^{12}$ Sehingga kualitas film akan semakin baik dan rapi dengan berkembangnya teknologi. Tidak hanya teknologi produksi film saja yang berkembang, teknologi penyiaran film pun berkembang. Penyiaran film yang awalnya hanya dilakukan dengan bioskop, kemudian televisi, melalui DVD, VCD, Laser Disc, hingga saat ini muncul penyiaran film melalui jaringan internet atau dikenal sebagai Over The Top (selanjutnya disebut OTT).

Penyiaran berbasis internet merupakan penyiaran yang dilakukan dengan jaringan internet melalui bandwidth atau spektrum. SVoD merupakan penggabungan Video on Demand (selanjutnya disebut VoD) dan OTT. VoD merupakan sistem penayangan yang memberikan fasilitas kepada pelanggan untuk menentukan tayangan apa yang ingin ditonton. SVoD merupakan VoD berbayar yang membayar untuk semua tayangan dengan batasan waktu hingga pelanggan membatalkan atau memberhentikan berlangganan [contoh dari layanan SVoD yaitu Netflix, Hulu Plus, HBO GO]. ${ }^{13}$

\footnotetext{
${ }^{7}$ Handrini Ardiyanti, 'Perfilman Indonesia: Perkembangan dan Kebijakan, Sebuah Telaah dari Perspektif Industri Budaya', (2017) 22 Kajian.[165].

8 Selfi Ratna Furi, 'Sejarah Konvergensi Perfilman Global dan Perspektif Indonesia', Tugas akhir (Universitas Indonesia 2014).[14].

9 ibid.[15].

${ }^{10}$ Yakobus Christian Ardy Pambudi, 'Institut Film di Yogyakarta', Skripsi (Universitas Atma Jaya Yogyakarta 2010).[14].

${ }^{11}$ Yakobus Christian Ardy Pambudi, ibid.[15].

${ }^{12}$ Selfi Ratna Furi, Op.Cit.[19].

${ }^{13}$ Wayne Hickey, 'Next-Gen OTT Video-Services' Massive Impact on Networks' (Ciena, 2017) < https://www.ciena.com/> accessed 22 November 2020.
} 
Netflix masuk ke Indonesia dengan Open Source Software yang berarti melakukan pengolahan dengan kode sumber (source-code) yang tersebar dan tersedia bebas. ${ }^{14}$ Bisnis yang dilakukan oleh Netflix yaitu bermitra dengan penyedia konten untuk memberikan hak lisensi pada film yang akan disiarkan pada pelanggan melalui platformnya. ${ }^{15}$ Netflix juga memproduksi konten original sendiri atau lebih dikenal sebagai Netflix Original. Keunggulan Netflix lainnya yaitu Netflix memiliki exclusive content sebanyak lebih dari 1650 (seribu enam ratus lima puluh) konten per 1 September 2020. ${ }^{16}$ Netflix membuat system rekomendasi yang membantu memudahkan pelanggan untuk memilih film berdasarkan jenis film yang sering diputar, perangkat lunak yang stabil agar tidak terjadi bug maupun lag, serta menonton setiap saat tanpa iklan. ${ }^{17}$

Berdasarkan data Techcrunch, Netflix jumlah pelanggan Netflix secara global per Februari 2020 berjumlah 167 (seratus enam puluh tujuh) juta. ${ }^{18}$ Sedangkan di Indonesia, jumlah pelanggan Netflix diperkirakan mencapai 900.000 (Sembilan ratus ribu) pelanggan berdasarkan analisis Nakono terhadap peningkatan jumlah pelanggan Netflix di Indonesia pada tahun 2017 hingga 2019 yang rata-rata meningkat hingga 2 (dua) kali lipat dari tahun sebelumnya. ${ }^{19}$ Pada kuartal ketiga tahun 2020, Netflix secara global memperoleh pendapatan lebih dari 6,44 miliar dolar AS yang menunjukkan peningkatan lebih dari 5,24 miliar pada kuartal ketiga tahun 2019. ${ }^{20}$ Sedangkan berdasarkan analisis Nakono. pendapatan Netflix di Indonesia pada tahun 2020 diperkirakan mencapai 76,6 juta dolar AS yang berarti

\footnotetext{
${ }^{14}$ Netflix, 'Open Source Software Center', (Netflix, 2020) <www.netflix.github.io> accessed 23 November 2020.

${ }^{15}$ Netflix, 'Bagaimana cara Netflix memberi lisensi acara TV dan film?', (Netflix, 2020) $<$ https://help.netflix.com/id/node/4976> accessed 16 Desember 2020.

${ }^{16}$ Rahmatunnisa, 'Murah Mana Netflix, Disney Plus, atau Amazon Prime?', (detikInet, 2020) $<$ https://inet.detik.com $>$ accessed 22 November 2020.

${ }^{17}$ Admin, 'Netflix Business Model (2020) | How does Netflix make money', (bstrategyhub, 2020) $<$ https://bstrategyhub.com> accessed 16 Desember 2020.

${ }^{18}$ Yosepha Pusparisa, 'Perbandingan Jumlah Pelanggan Layanan Streaming', (databoks, $2020)<$ https://databoks.katadata.co.id/> accessed 16 Desember 2020.

${ }^{19}$ Databoks, 'Berapa Pelanggan Streaming Netflix di Indonesia?', (databoks, 2019) <https:// databoks.katadata.co.id/> accessed 16 Desember 2020.

${ }^{20}$ Amy Watson, 'Revenue generated by Netflix from 1st quarter 2011 to 3rd quarter 2020', (statista, 2020) <https://www.statista.com/> accessed 16 Desember 2020.
} 
meningkat 2 (dua) kali dari pendapatan pada tahun 2019. ${ }^{21}$ Pendapatan tersebut diperoleh dari satu-satunya sumber pendapatan Netflix yaitu pelanggannya.

Kehadiran Netflix disambut baik oleh operator telekomunikasi Indonesia, antara lain XL Axiata, Bolt, dan Hutchison Tri yang dengan bekerja sama menyediakan paket streaming khusus Netflix pada tahun 2018.22 Namun, terdapat persoalan antara Netflix dengan Indonesia, yaitu Telkom yang memblokir Netflix sejak tahun 2016 hingga pada Juli 2020 tanpa perintah dari Kementerian Kominfo dengan alasan Telkom menganggap Netflix harus ada izin usaha, serta konten yang disiarkan Netflix bertentangan dengan Pasal 57 UU Perfilman yang mewajibkan memperoleh STLS juga kontennya bertentangan dengan peraturan perundangundangan lainnya. ${ }^{23}$ Persoalan setelah Telkom membuka blokir yaitu Netflix diminta untuk memindahkan server yang ada di Singapura ke Indonesia karena pipa jaringan didominasi oleh traffic Netflix. ${ }^{24}$ Pengurus Harian Yayasan Lembaga Konsumen Indonesia (YLKI), Sudaryatmo, meminta Kominfo untuk memblokir (take down) konten Netflix yang bermuatan SARA, pornografi, dan melanggar norma kesusilaan serta meminta pemerintah memberi edukasi masyarakat Indonesia dengan menekankan parenting guideline. ${ }^{25}$ Kemudian Sudaryatmo menambahkan bahwa Netflix harus membentuk BUT di Indonesia agar konsumen bisa langsung menuntut Ketika ada masalah. ${ }^{26}$

Perkembangan peraturan terkait perfilman, antara lain Film Ordonnantie, Staatblad van Nederlaandsch Indie No.276 yang dikeluarkan pada tanggal 18 Maret 1961 mengenai pembentukan komisi sensor di 4 (empat) kota yakni Batavia,

${ }^{21}$ Admin, 'Pendapatan streaming Netflix di Indonesia, 2017-2020', (lokadata, 2020) <https:// lokadata.beritagar.id/> accessed 16 Desember 2020.

${ }^{22}$ Wahyunanda Kusuma Pertiwi, 'XL, Tri, dan Bolt Sediakan Paket “Streaming” Netflix', (Kompas.com, 2018) <https://tekno.kompas.com/> accessed 30 Desember 2020.

${ }^{23}$ Admin, 'Alasan Telkom Blokir Netflix: Semua Film Wajib Lulus Sensor', (Tekno, 2016) $<$ https://bisnis.tempo.co/> accessed 16 Desember 2020.

${ }^{24}$ Dal, 'Usik Internet Publik, Telkom Minta Netflix Buka Server di RI', (CNN Indonesia, $2020)<$ https://www.cnnindonesia.com/> accessed 23 November 2020.

${ }^{25}$ Admin, 'YLKI: Pemerintah Harus Blokir Konten Porno dan LGBT Netflix', (CNN Indonesia, 2020) <https://www.cnnindonesia.com/> accessed 16 Desember 2020.

${ }^{26}$ Arif Budiansyah, 'Telkom Group Blokir Netflix, Langgar Aturankah?', (CNBC Indonesia, 2020) <https://www.cnbcindonesia.com/> accessed 16 Desember 2020. 
Surabaya, Semarang, dan Medan karena kekhawatiran pemerintah kolonial terhadap penonton terkait pengaruh film impor yang bermuatan isi perkelahian, tembak-menembak, dan pergaulan bebas maka. Kemudian pada tahun 1925, diterbitkan peraturan mengenai kriteria sensor film, namun sensor film ini menjadi polemik karena prosentase film tidak lolos sensor meningkat dari tahun ke tahun akibat mekanisme sensor film yang ketat. ${ }^{27}$ Pada tahun 1977, Pemerintah Indonesia mengeluarkan Surat Keputusan Menteri mengenai pedoman sensor. ${ }^{28}$ Sampai akhirnya dikeluarkannya Undang-Undang Nomor 8 Tahun 1992 tentang Perfilman yang berlaku pada tahun 1992 hingga dicabut oleh UU Perfilman pada tahun 2009.

Peraturan perundang-undangan terkait penyiaran berbasis internet, antara lain UU Penyiaran, UU Perfilman, Undang-Undang Nomor 44 Tahun 2008 tentang Pornografi (selanjutnya disebut UU Pornografi), dan UU ITE. Kegiatan yang dilakukan oleh Netflix merupakan kegiatan penyiaran menurut UU Penyiaran. Secara konsep kegiatan Netflix hampir sama dengan LPB yang menyediakan siaran pada pelanggan khusus yang telah membayar untuk berlangganan. Namun, dalam Pasal 26 ayat (1) UU Penyiaran tidak menyebutkan melalui internet atau memberikan peluang media lain untuk diatur oleh Pasal tersebut seperti pada Pasal 1 angka 2 UU Penyiaran dan Penjelasan Umum UU Penyiaran dengan kata lain tidak diatur secara eksplisit lembaga penyiaran jenis apa yang berhak menyiarkan melalui internet. Faktanya Netflix tidak berbadan hukum dan tidak didirikan oleh warga Negara Indonesia. Sehingga dalam hal ini Netflix tidak memenuhi sebagai Lembaga penyiaran atau sebagai subjek hukum UU Penyiaran serta tidak memiliki hak dan kewajiban yang diatur UU Penyiaran. Netflix tidak memiliki hak melakukan penyiaran dikarenakan hanya Lembaga penyiaran yang menyelenggarakan penyiaran.

Berdasarkan UU Perfilman, Netflix sebagai pelaku usaha pertunjukan film melalui jaringan teknologi informatika yang dilakukan melalui jaringan teknologi informatika diharuskan berbadan usaha badan hukum Indonesia namun Netflix

${ }^{27}$ Elvy Maria Manurung, 'Paradoks dan Manajemen Kreativitas dalam Industri Film Indonesia', Disertasi (Universitas Kristen Satya Wacana 2016.[70].

${ }^{28}$ Elvy Maria Manurung, ibid.[82]. 
tidak memiliki izin usaha. ${ }^{29}$ Izin usaha tersebut diberikan sesuai dengan ketentuan peraturan perundang-undangan yang berlaku, dalam hal ini UU ITE. Pada UU ITE sendiri mengkategorikan Netflix sebagai PSE Lingkup Privat. Sebelum adanya PP 71/2019, PP 36/2014 mengatur bahwa PSE Lingkup Privat dapat melakukan pendaftaran yang artinya boleh dilakukan dan boleh tidak dilakukan. Sehingga diatur ketentuan peralihan bahwa PSE yang sudah berjalan sebelum PP 71/2019 maka diberi waktu penyesuaian mengenai pendaftaran selama 1 (satu) tahun pada saat PP 71/2019 berlaku. ${ }^{30}$ Namun, Netflix tidak mendaftarkan diri sebagai PSE Lingkup Privat hingga saat ini lewat 1 (satu) tahun sejak berlakunya PP 71/2019.

Kominfo mengeluarkan Permenkominfo 5/2020 yang mengatur ketentuan peralihan bahwa PSE Lingkup Privat diwajibkan melaksanakan pendaftaran dalam rentang waktu paling lama 6 (enam) bulan sejak Peraturan Menteri ini berlaku. ${ }^{31}$ Sehingga untuk saat ini Netflix melanggar Pasal 6 ayat (1) PP 71/2019. Jika Netflix tidak melakukan pendaftaran hingga telah lewat 6 (enam) bulan sejak berlakunya Permenkominfo 5/2020, maka Netflix melanggar Pasal 2 Permenkominfo 5/2020. Sebaliknya, Netflix tidak melanggar Pasal 2 Permenkominfo 5/2020 jika Netflix telah melakukan pendaftaran hingga sebelum lewat 6 (enam) bulan sejak berlakunya Permenkominfo 5/2020.

Isi siaran yang disiarkan Netflix termasuk bertentangan dengan ketentuan peraturan perundang-undangan di Indonesia. Beberapa film yang disiarkan Netflix yang cukup mengundang kontroversi antara lain, Film Cuties tayang pada 9 September 2020 yang memuat adegan seksual dan melibatkan anak-anak, Film 13 Reason Why tayang pada 31 Maret 2017 yang memuat adegan bunuh diri secara terang-terangan, Film 365 days tayang pada 7 Februari 2020 yang memuat adegan seksual, Win It All tayang pada 11 Maret 2017 yang memuat perjudian dan masih banyak lagi film-film Netflix yang mengundang kontroversi karena bertentangan

\footnotetext{
${ }^{29}$ Pasal 29 Undang-Undang Nomor 33 Tahun 2009 tentang Perfilman.

${ }^{30}$ Pasal 102 ayat (1) Peraturan Pemerintah Nomor 71 Tahun 2019 tentang Penyelenggaraan Sistem dan Teransaksi Elektronik.

${ }^{31}$ Pasal 47 Peraturan Menteri Komunikasi dan Informatika Nomor 5 Tahun 2020 tentang Penyelenggara Sistem Elektronik Lingkup Privat.
} 
dengan Peraturan Perundang-Undangan di Indonesia. Berdasarkan UU Penyiaran, film-film Netflix bermuatan kekerasan, cabul, dan perjudian bertentangan dengan larangan isi siaran pada Pasal 36 ayat (5) UU Penyiaran, Pedoman Perilaku Penyiaran, dan Standar Program Siaran.

MenurutUU Perfilman, film-film Netflix termasuk film menurut UU Perfilman. Namun, film-film tersebut yang akan diedarkan dan dipertunjukan di Indonesia tidak melalui proses penyensoran oleh LSF yang diwajibkan Pasal 57 UU Perfilman sehingga bermuatan kekerasan, perjudian, dan pornografi yang dilarang Pasal 6 UU Perfilman. Sedangkan menurut UU Pornografi, film-film Netflix bertentangan dengan Pasal 4 ayat (1) UU Pornografi karena memproduksi, menyebarluaskan, menyewakan, atau menyediakan yang mengandung muatan pornografi dan Pasal 11 UU Pornografi karena melibatkan anak sebagai objek dalam melakukan perbuatan Pasal 4 UU Pornografi. Selain itu, Netflix juga dapat dikatakan melanggar Pasal 27 ayat (1) dan (2) UU ITE karena mendistribusikan filmnya yang merupakan Informasi Elektronik bermuatan kesusilaan dan perjudian.

\section{Pertanggungjawaban Hukum Netflix Terkait Penyiaran Film Tanpa Sensor}

Tanggung jawab hukum yaitu kewajiban suatu perbuatan yang diatur dalam aturan atau norma hukum pada peraturan perundang-undangan yang harus dilakukan subjek hukum dengan disertai tanggung jawab hukum karena akan dapat dikenai disalahkan, sanksi, dituntut, atau bahkan diperkarakan jika tidak dilaksanakan sesuai dengan aturan atau norma hukum pada peraturan perundangundangan. Dalam hukum teknologi informasi, prinsip yurisdiksi ekstrateritorial merupakan prinsip utama yang telah diatur dalam Pasal 2 UU ITE. Hal tersebut ada karena dalam memanfaatkan teknologi informasi dan komunikasi untuk informasi elektronik dan transaksi elektronik dapat melintasi territorial atau universal sehingga suatu perbuatan yang merugikan negara maupun orang dapat dilakukan di wilayah negara lain atau dengan kata lain perbuatan melalui teknologi yang tidak menganal wilayah (borderless). Merugikan kepentingan Indonesia dalam Pasal 2 UU ITE memiliki maksud bahwa meliputi perlindungan data strategis, merugikan 
kepentingan ekonomi nasional, harkat martabat bangsa, pertahanan dan keamanan negara, kedaulatan negara, warga negara serta badan hukum Indonesia. Sehingga Netflix sebagai penyedia layanan SVoD yang berdasarkan peraturan perundangundangan termasuk PSE Lingkup Privat yang melakukan penyiaran film di luar wilayah Indonesia dapat dikenai tanggung jawab hukum.

Teori hukum umum membagi tanggung jawab hukum menjadi berupa tanggung jawab pidana, tanggung jawab perdata, dan tanggung jawab administrasi yang. ${ }^{32}$ Dalam peraturan perundang-undangan yang mengatur PSE yang menyiarkan film, terdapat tanggung jawab secara pidana, tanggung jawab secara perdata dan tanggung jawab secara administratif. Tanggung jawab hukum Netflix secara pidana dapat dilihat dari bentuk ketentuan pidana yang dijatuhkan atas perbuatannya yang bertentangan dengan peraturan perundang-undangan. Tanggung jawab hukum Netflix secara perdata dapat dilihat dari gugatan yang diberikan atas pelanggaran terhadap kewajiban yang dibebankan kepada Netflix. Tanggung jawab hukum Netflix secara administratif dapat dilihat dari bentuk sanksi administrative yang diberikan atas pelanggaran terhadap kewajiban yang dibebankan kepada Netflix.

Dalam tanggung jawab secara pidana, tidak dipidana jika tidak ada kesalahan (Green straf zonder schuld; Actus non facit reum nisi mens sist rea). ${ }^{33}$ Menurut Moeljatno, perlu dipenuhi syarat-syarat dalam menuntut tanggung jawab secara pidana, antara lain: ${ }^{34}$

1. Telah melakukan perbuatan pidana (sifat melawan hukum);

2. Kemampuan bertanggung jawab seseorang yang telah melakukan perbuatan pidana;

3. Terdapat bentuk kesalahan yang berupa kesengajaan (dolus) atau kealpaan (culpa);

4. Tidak memiliki alasan pembenar maupun alasan pemaaf.

\footnotetext{
${ }^{32}$ Mody Gregorian Baurch, 'Pertanggungjawaban Hukum Dewan Perwakilan Rakyat Dalam Proses Legislasi Terhadap Implikasi Putusan Mahkamah Konstitusi Atas Pengujian Undang-Undang', Thesis (Universitas Atma Jaya Yogyakarta 2013).[20]., dikutip dari Munir Fuady, Teori Negara Hukum Modern (Refika Aditama 2009).[147].

${ }^{33}$ Moeljatno, Asas-Asas Hukum Pidana (Rineka Cipta 2008).[165].

${ }^{34}$ ibid.[177].
} 
Korporasi memiliki pengertian yaitu kumpulan orang dan kekayaan yang terorganisir berupa badan hukum dan bukan badan hukum. ${ }^{35}$ Sehingga korporasi sebagai subjek/pelaku tindak pidana dalam UU Perfilman, UU Pornografi dan UU ITE mengatur tindak pidana korporasi. Dikatakan sebagai tindak pidana korporasi, apabila tindak pidana tersebut dilakukan oleh pengurus atau orang yang: ${ }^{36}$

a. Mewakili korporasi untuk melakukan perbuatan hukum;

b. Memiliki kedudukan berwenang mengambil keputusan atas nama korporasi;

c. Berwenang melakukan pengawasan pengendalian korporasi tersebut;

d. Melakukan kegiatan demi keuntungan.

Dalam tindak pidana korporasi, terdapat penyertaan. KUHP membagi penyertaan kedalam dua kategori, yaitu kategori pertama sebagai pelaku (dader), terdiri dari orang yang melakukan (plager), menyuruh melakukan (middelijke daderschap), turut melakukan (medeplegen), dan membujuk (uitlokker). ${ }^{37}$ Kategori kedua sebagai pembantu (medeplichters). ${ }^{38}$

Berdasarkan perbuatan Netflix di atas, Netflix sebagai korporasi yang memenuhi unsur tindak pidana sebagai pelaku dengan ketentuan sanksi pidana yang diatur oleh UU Penyiaran, UU Perfilman, UU Pornografi, dan UU ITE, yaitu Pasal 57 UU Penyiaran, Pasal 80, Pasal 82, Pasal 82 ayat (3) UU Perfilman Pasal 29, Pasal 37, Pasal 40 ayat (7), Pasal 41 UU Pornografi, Pasal 45 ayat (1), Pasal 52 ayat (1), dan Pasal 52 ayat (4) UU ITE. Locus kegiatan penyiaran film tanpa sensor yang dilakukan oleh Netflix tidak dapat dijangkau oleh UU Perfilman sehingga Netflix tidak dapat diterapkan atau diatur dengan UU Perfilman. Dalam UU ITE dapat menjangkau locus kegiatan penyiaran film tanpa sensor yang dilakukan oleh Netflix di luar wilayah Indonesia, sebagaimana diatur dalam Pasal 2 UU ITE memiliki asas ekstrateritorial sehingga UU ITE dapat menerapkan atau mengatur terhadap Netflix.

\footnotetext{
${ }^{35}$ Pasal 1 angka 1 Peraturan Mahkamah Agung Nomor 13 Tahun 2016 tentang Tata Cara Penanganan Perkara Tindak Pidana Oleh Korporasi.

${ }^{36}$ Pasal 83 Undang-Undang Nomor 33 Tahun 2009 tentang Perfilman, Pasal 40 Undang-Undang Nomor 44 Tahun 2008 tentang Pornografi, Penjelasan Pasal 52 ayat (4) Undang-Undang Nomor 11 Tahun 2008 jo. Undang-Undang Nomor 19 Tahun 2016 Tentang Informasi Dan Transaksi Elektronik.

${ }^{37}$ Pasal 55 Undang-Undang Nomor 1 Tahun 1946 tentang Peraturan Hukum Pidana (KUHP).

${ }^{38}$ Pasal 56 Undang-Undang Nomor 1 Tahun 1946 tentang Peraturan Hukum Pidana (KUHP).
} 
Dengan demikian UU ITE lebih sesuai diterapkan terhadap Netflix daripada UU Penyiaran, UU Perfilman, dan UU Pornografi.

Dasar tanggung jawab secara perdata dibagi menjadi 2 (dua), yaitu wanprestasi dan perbuatan melanggar hukum.. UU ITE mengatur bahwa setiap orang atau masyarakat secara perwakilan dapat mengajukan gugatan sesuai dengan ketentuan peraturan perundang-undangan terhadap yang menyelenggarakan sistem elektronik dan teknologi informasi apabila dalam menyelenggarakannya menimbulkan kerugian. ${ }^{39}$

Pengenaan sanksi administratif tidak menghilangkan tanggung jawab secara pidana dan perdata. ${ }^{40}$ Dalam UU Perfilman, menyebutkan bentuk sanksi administrative, antara lain berupa: ${ }^{41}$

a. Teguran tertulis;

b. Denda administratif;

a. Penutupan sementara; dan/atau

b. Pembubaran atau pencabutan izin.

Dalam UU ITE, kemudian diatur lebih lanjut dalam PP 71/2019 menyebutkan bentuk sanksi administrative, antara lain berupa: ${ }^{42}$

a. Teguran tertulis;

b. Denda administratif;

c. Penghentian sementara;

d. Pemutusan akses;

e. Pencabutan Tanda Daftar Penyelenggara Sistem Elektronik.

Netflix sebagai PSE Lingkup Privat yang tidak mendaftarkan diri dan memiliki informasi elektronik dan dokumen elektronik yang dilarang maka dikenai sanksi administratif. PP 71/2019 tidak menyebutkan sanksi administrasi yang berupa apa ketika tidak mendaftarkan diri, namun Permenkominfo 5/2020 mengatur akan dikenai sanksi administratif berupa pemutusan akses jika tidak melakukan

\footnotetext{
${ }^{39}$ Pasal 38 Undang-Undang Nomor 11 Tahun 2008 jo. Undang-Undang Nomor 19 Tahun 2016 Tentang Informasi Dan Transaksi Elektronik.

${ }^{40}$ Pasal 100 ayat (5) Peraturan Pemerintah Nomor 71 Tahun 2019 tentang Penyelenggaraan Sistem dan Teransaksi Elektronik.

${ }^{41}$ Pasal 79 Undang-Undang Nomor 33 Tahun 2009 tentang Perfilman.

${ }^{42}$ Pasal 100 Peraturan Pemerintah Nomor 71 Tahun 2019 tentang Penyelenggaraan Sistem dan Teransaksi Elektronik, Pasal 45 ayat (4) Peraturan Menteri Komunikasi dan Informatika Nomor 5 Tahun 2020 tentang Penyelenggara Sistem Elektronik Lingkup Privat.
} 
pendaftaran dan akan diberi teguran tertulis, denda, dan/atau pencabutan akses jika memiliki informasi elektronik dan dokumen elektronik yang dilarang.

Operator telekomunikasi yang bekerja sama dengan Netflix merupakan penyelenggara telekomunikasi sebagaimana disebut pada Pasal 1 angka 12 Undang-Undang Nomor 36 Tahun 1999 tentang Telekomunikasi (selanjutnya disebut UU Telekomunikasi). Dalam UU Telekomunikasi, terdapat salah satu larangan bahwa penyelenggara telekomunikasi tidak boleh melaksanakan kegiatan usaha penyelenggaraan telekomunikasi yang bertentangan dengan kepentingan umum, ketertiban umum, kesusilaan, atau keamanan. ${ }^{43}$ XL Axiata, Bolt, dan Hutchison Tri yang melakukan kerja sama dengan Netflix berupa menyediakan Paket Streaming khusus Netflix atau menerima pembayaran dari pelanggan Netflix padahal film yang disiarkan Netflix merupakan film tanpa sensor yang terindikasi bermuatan kekerasan, maupun bermuatan pornografi. Sehingga kegiatan usaha yang dilakukan oleh 3 (tiga) operator telekomunikasi tersebut melanggar Pasal 21 UU Telekomunikasi dilanggar yang dapat dikenai sanksi administrasi berupa pencabutan izin setelah diberi peringatan tertulis. ${ }^{44}$ Selain itu, adanya tanggung jawab secara perdata bahwa pihak yang dirugikan atas kelalaian maupun kesalahan penyelenggara telekomunikasi memiliki hak mengajukan tuntutan ganti rugi kepada penyelenggara telekomunikasi. ${ }^{45}$ Namun, berdasarkan Pasal 56 KUHP operator telekomunikasi sebagai penyedia internet yang bekerja sama dengan Netflix dapat dimungkinkan dikatakan sebagai pembantuan tindak pidana yang dilakukan oleh Netflix karena operator telekomunikasi memudahkan Netflix untuk menyebarkan film-filmnya yang bermuatan kesusilaan, kekerasan, dan perjudian kepada pelanggan Netflix..

Terdapat beberapa negara yang melakukan penindakan terhadap Netflix, yaitu, Kenya Film Classification Board (KFCB) melarang Netflix 2 (dua) minggu setelah diluncurkan di negara itu dengan alasan layanan tersebut menjadi ancaman bagi nilai-

\footnotetext{
${ }^{43}$ Pasal 21 Undang-Undang Nomor 36 Tahun 1999 tentang Telekomunikasi.

${ }^{44}$ Pasal 45, 46 Undang-Undang Nomor 36 Tahun 1999 tentang Telekomunikasi.

${ }^{45}$ Pasal 17 Undang-Undang Nomor 36 Tahun 1999 tentang Telekomunikasi.
} 
nilai moral dan keamanan nasional. ${ }^{46}$ Rencana untuk mengatur layanan streaming dengan National Information and Communications Technology (ICT) Policy 2016 muncul beberapa bulan setelah lembaga Pemerintah lainnya memperingatkan Netflix bahwa mereka akan memblokir layanan jika menayangkan konten yang tidak pantas. ${ }^{47}$ Pada tahun 2020, Kenya Revenue Authority akan membuat regulasi ekonomi agar Netflix dapat membayar pajak. ${ }^{48}$

British Board of Film Classification (BBFC) mengizinkan Netflix untuk menilai kontennya sendiri dan menentukan penggolangan berdasarkan usia sesuai dengan pedoman BBFC. BBFC yang pertama kali membiarkan perusahaan menilai kontennya sendiri, maka akan melakukan audit bulanan pada konten tertentu untuk memastikan Netflix memenuhi kesepakatannya yaitu mencapai standar BBFC 95\% dari waktu ke waktu untuk mempertahankan kemampuannya menilai kontennya. ${ }^{49}$ Di Australia, Setelah Netflix uji coba selama dua tahun di Australia dan alat Netflix dinyatakan dapat menilai dan mengklasifikasikan konten dengan akurasi 96\%, maka Netflix diizinkan untuk mengklasifikasi kontennya sendiri. ${ }^{50}$

Communications and Information Technology Commission Arab Saudi, Singapura, Selandia Baru, Vietnam, dan Jerman. Infocomm Media Development Authority (IMDA) Singapura meminta Netflix untuk mengirim permintaan menghapus konten di Netflix. Netflix telah memenuhi perminatan tertulis tersebut dan mengatakan bahwa mulai 2021 akan melaporkan pemberitahuan mengenai take down setiap tahun. ${ }^{51}$

\footnotetext{
${ }^{46}$ Ikigai Law, 'Online content regulation: how is it done in other parts of the world?', (Ikigailaw, 2019) <https://www.ikigailaw.com/> accessed 19 Desember 2020.

${ }^{47}$ Frankline Sunday, 'Kenyan State to regulate YouTube and Netflix', (The Standard, 2016), $<$ https://www.standardmedia.co.ke/> accessed19 Desember 2020.

${ }^{48}$ Paula Gilbert, 'East Africa's digital economy needs progressive policy - Kenyan regulator', (connectingafrica, 2020) <http://www.connectingafrica.com/> accessed 19 Desember 2020.

${ }^{49} \mathrm{Jim}$ Waterson, 'Netflix to set its own age ratings for film and television programmes', (theguardian, 2019) < https://www.theguardian.com/> accessed 19 Desember 2020.

${ }^{50}$ The Sydney Morning Herald, 'Netflix gets approval to classify own shows after two-year trial', (smh, 2019) <https://www.smh.com.au/> accessed 19 Desember 2020.

${ }^{51}$ Samit Sarkar, 'Netflix reveals the 9 times it has complied with government censorship', (polygon, 2020) <https://www.polygon.com/> accessed 19 Desember 2020.
} 


\section{Kesimpulan}

Peraturan perundang-undangan yang terkait penyiaran film berbasis internet, antara lain UU Penyiaran, UU Perfilman, UU Pornografi, dan UU ITE beserta peraturan pelaksananya. Netflix tidak dapat digolongkan sebagai Lembaga penyiaran, melainkan hanya sebagai PSE yang menyiarkan film karena UU Penyiaran tidak mengatur secara rinci untuk Lembaga penyiaran berbasis internet, namun hingga saat ini Netflix belum mendaftarkan diri sebagai PSE. Setiap film yang masuk di Indonesia wajib dilakukan penyensoran oleh LSF walaupun memiliki sensor internal sendiri. Film yang disiarkan Netflix di Indonesia merupakan film yang diwajibkan untuk sensor, namun film yang disiarkan Netflix tidak melalui sensor oleh LSF sehingga memiliki muatan yang melanggar ketentuan peraturan perundang-undangan. Selain itu, Netflix juga melanggar komitmennya untuk mematuhi Self-Regulatory Subscription Video-on-Demand Industry Content Code in Association of Southeast Asian Nations.

Netflix yang melakukan kegiatan penyiaran film tanpa sensor di luar wilayah Indonesia tidak dapat dimintai pertanggungjawaban hukum dengan UU Penyiaran, UU Perfilman, dan UU Pornografi karena tidak terjangkaunya yurisdiksi, sehingga hanya dengan UU ITE berdasarkan asas ekstrateritorial yang diatur Pasal 2 UU ITE. Tanggung jawab hukum tersebut meliputi tanggung jawab secara pidana, perdata, dan administratif, namun hingga saat ini tidak ada pertanggungjawaban hukum oleh Netflix. Dalam melakukan penyiaran, Netflix bekerja sama dengan operator telekomunikasi di Indonesia yang membantu menerima pembayaran dari pelanggan Netflix. Operator telekomunikasi tersebut melanggar UU Telekomunikasi dikenai sanksi administratif dan perdata. Namun, berdasarkan Pasal 56 KUHP operator telekomunikasi sebagai penyedia internet yang bekerja sama dengan Netflix dapat dimungkinkan dikatakan sebagai pembantuan tindak pidana yang dilakukan oleh Netflix. Selain itu, pada beberapa Negara telah dilakukan tindakan terhadap Netflix, baik berupa take down maupun pengawasan secara langsung atau tidak langsung. 


\section{Daftar Bacaan}

\section{Buku}

Moeljatno, Asas-Asas Hukum Pidana (Rineka Cipta 2008).

Peter Mahmud Marzuki, Penelitian Hukum (Prenadamedia Group 2019).

\section{Jurnal}

Handrini Ardiyanti, 'Perfilman Indonesia: Perkembangan dan Kebijakan, Sebuah Telaah dari Perspektif Industri Budaya' (2017) 22 Kajian.

\section{Makalah}

Elvy Maria Manurung, 'Paradoks dan Manajemen Kreativitas dalam Industri Film Indonesia', Disertasi (Universitas Kristen Satya Wacana 2016).

Mody Gregorian Baurch, 'Pertanggungjawaban Hukum Dewan Perwakilan Rakyat Dalam Proses Legislasi Terhadap Implikasi Putusan Mahkamah Konstitusi Atas Pengujian Undang-Undang', Thesis (Universitas Atma Jaya Yogyakarta 2013).

Selfi Ratna Furi, 'Sejarah Konvergensi Perfilman Global dan Perspektif Indonesia', Tugas akhir (Universitas Indonesia 2014).

Yakobus Christian Ardy Pambudi, 'Institut Film di Yogyakarta', Skripsi Universitas Atma Jaya Yogyakarta 2010).

\section{Laman}

Admin, 'Alasan Telkom Blokir Netflix: Semua Film Wajib Lulus Sensor', (Tekno, 2016) <https://bisnis.tempo.co/>.

Admin, 'Netflix Business Model (2020) | How does Netflix make money', (bstrategyhub, 2020) <https://bstrategyhub.com>.

Admin, 'Pendapatan streaming Netflix di Indonesia, 2017-2020', (lokadata, 2020) $<$ https://lokadata.beritagar.id/>.

Admin, 'YLKI: Pemerintah Harus Blokir Konten Porno dan LGBT Netflix', (CNN Indonesia, 2020) <https://www.cnnindonesia.com/ $>$.

Amy Watson, 'Revenue generated by Netflix from 1st quarter 2011 to 3rd quarter 2020', (statista, 2020) <https://www.statista.com/>. 
Arif Budiansyah, 'Telkom Group Blokir Netflix, Langgar Aturankah?', (CNBC Indonesia, 2020) <https://www.cnbcindonesia.com/>.

Conney Stephanie, 'Netflix Diunduh Lebih dari 1 Miliar Kali di Google Play Store', (Kompas.com, 2020) <https://tekno.kompas.com/ >.

Dal, 'Usik Internet Publik, Telkom Minta Netflix Buka Server di RI', (CNN Indonesia, 2020) <https:/www.cnnindonesia.com/> accessed 23 November 2020 .

Databoks, 'Berapa Pelanggan Streaming Netflix di Indonesia?', (databoks, 2019) $<$ https://databoks.katadata.co.id/>.

Frankline Sunday, 'Kenyan State to regulate YouTube and Netflix', (The Standard, 2016), <https://www.standardmedia.co.ke/>.

Ikigai Law, 'Online content regulation: how is it done in other parts of the world?', (Ikigai Law, 2019) <https://www.ikigailaw.com/ >.

Jim Waterson, 'Netflix to set its own age ratings for film and television programmes', (theguardian, 2019) $<$ https://www.theguardian.com/>.

Khamila Mulia, 'Netflix's complicated relationship with Indonesia', (Techinasia, 2020) <https://www.techinasia.com/>.

Netflix, 'Bagaimana cara Netflix memberi lisensi acara TV dan film?', (Netflix, 2020) $<$ https://help.netflix.com/id/node/4976> .

Netflix, 'Open Source Software Center', (Netflix, 2020) <www.netflix.github.io>.

Paula Gilbert, 'East Africa's digital economy needs progressive policy - Kenyan regulator', (connectingafrica, 2020) $<\mathrm{http}$ ://www.connectingafrica.com/ $/$.

Rahmatunnisa, 'Murah Mana Netflix, Disney Plus, atau Amazon Prime?', (detikInet, 2020) <https://inet.detik.com $〉$.

Samit Sarkar, 'Netflix reveals the 9 times it has complied with government censorship', (polygon, 2020) <https://www.polygon.com/>.

Sherly Puspita, 'Kominfo: UU Penyiaran Saat Ini Belum Akomodasi KPI Awasi Media Baru', (Kompas.com, 2019) <https://entertainment.kompas.com/>.

Techopedia, 'Subscription Video on Demand (SVoD)', (Techopedia, 2016) <https:// www.techopedia.com/>.

The Sydney Morning Herald, 'Netflix gets approval to classify own shows after 
two-year trial', (smh, 2019) <https://www.smh.com.au/>.

Wahyunanda Kusuma Pertiwi, 'XL, Tri, dan Bolt Sediakan Paket "Streaming" Netflix', (Kompas.com, 2018) <https://tekno.kompas.com/>.

Wayne Hickey, 'Next-Gen OTT Video-Services' Massive Impact on Networks' (Ciena, 2017) <https://www.ciena.com/>.

Yosepha Pusparisa, 'Perbandingan Jumlah Pelanggan Layanan Streaming', (databoks, 2020) <https://databoks.katadata.co.id/>.

\section{Peraturan Perundang-undangan}

Undang-Undang Nomor 1 Tahun 1946 tentang Peraturan Hukum Pidana (KUHP).

Undang-Undang Nomor 36 Tahun 1999 tentang Telekomunikasi.

Undang-Undang Nomor 11 Tahun 2008 Tentang Informasi Dan Transaksi Elektronik.

Undang-Undang Nomor 44 Tahun 2008 tentang Pornografi.

Undang-Undang Nomor 33 Tahun 2009 tentang Perfilman.

Peraturan Mahkamah Agung Nomor 13 Tahun 2016 tentang Tata Cara Penanganan Perkara Tindak Pidana Oleh Korporasi.

Undang-Undang Nomor 19 Tahun 2016 Tentang Informasi Dan Transaksi Elektronik.

Peraturan Pemerintah Nomor 71 Tahun 2019 tentang Penyelenggaraan Sistem dan Transaksi Elektronik.

Peraturan Menteri Komunikasi dan Informatika Nomor 5 Tahun 2020 tentang Penyelenggara Sistem Elektronik Lingkup Privat. 
Aushofi Zuhrotul: Aspek Hukum Pidana...

--halaman ini sengaja dibiarkan kosong-- 